Original Paper

\title{
Pemberdayaan Masyarakat Melalui Pengolahan Keripik Jagung (Zea Mays L.) dengan Bebrbagai Varian Rasa di Desa Babussalam, Kecamatan Gerung, Kabupaten Lombok Barat
}

\author{
Aris Doyan ${ }^{1 *}$, Inggit Garnasih ${ }^{2}$, Taqiudin Subki ${ }^{3}$, M. Agung Algifaari ${ }^{1}$, Resda Brahma \\ Alam ${ }^{4}$, Husnul Hotimah ${ }^{2}$, Nunung Apriana ${ }^{1}$, Winda Permatasari ${ }^{3}$, Irmawati ${ }^{4}$, Ariadi $^{5}$, \\ Annisa Pratiwi6
}

\author{
${ }^{1}$ Fakultas Keguruan dan Ilmu Pengetahuan, Universitas Mataram, Indonesia; \\ 2 Fakultas Matematika dan Ilmu Pengetahuan Alam, Universitas Mataram, Indonesia; \\ ${ }^{3}$ Fakultas Hukum, Universitas Mataram, Indonesia; \\ ${ }^{4}$ Fakultas Teknik, Universitas Mataram, Indonesia; \\ ${ }^{5}$ Fakultas Teknik Pangan, Universitas Mataram, Indonesia; \\ ${ }^{6}$ Fakultas Pertanian, Universitas Mataram, Indonesia.
}

DOI: $10.29303 /$ jpmpi.v3i1.415

Sitasi: Doyan, A., Garnasih, I., Garnasih, I., Algifaari, M., Alam, R., Hotimah, H., Apriana, N., Permatasari, W., Irmawati, I., Ariadi, A., \& Pratiwi, A. (2020). Pemberdayaan Masyarakat Melalui Pengolahan Keripik Jagung (Zea Mays L.) dengan Bebrbagai Varian Rasa di Desa Babussalam, Kecamatan Gerung, Kabupaten Lombok Barat. Jurnal Pengabdian Magister Pendidikan IPA, 3(1). doi:https://doi.org/10.29303/jpmpi.v3i1.415

\footnotetext{
*Corresponding Author: Aris DOyan, Fakultas Keguruan dan Ilmu Pengetahuan, Universitas Mataram, Indonesia, Indonesia; Email: arisdoyan@yahoo.com
}

\begin{abstract}
Abstrak: Jagung (Zea mays L.) merupakan komoditas pertanian yang memiliki sekitar 50.000 varietas, salah satunya yaitu jagung manis (Zea mays saccharata) sangat digemari terutama oleh penduduk perkotaan karena memiliki cita rasa yang lezat. Desa Babussalam memiliki Sumber Daya Alam (SDA) yang sangat melimpah. SDA tertinggi yang dimiliki desa Babussalam yaitu tanaman jagung. Desa Babussalam juga kaya akan Sumber Daya Manusia (SDM). Hal ini dapat dibuktikan dengan luas permukiman seluas $14,918 \mathrm{ha} / \mathrm{m}^{2}$ dengan jumlah penduduk sebanyak 9.278 jiwa. Kendala yang terlihat di desa ini adalah kurangnya kesadaran masyarakat tentang pengolahan bahan mentah menjadi produk jadi yang memiliki nilai ekonomi yang tinggi. Alternatif yang dapat dilakukan untuk mengatasi kendala tersebut adalah "Pembedayaan Masyarakat Melalui Pengolahan Keripik Jagung (Zea mays L.) dengan Berbagai Varian Rasa di Desa Babussalam, Kecamatan Gerung, Kabupaten Lombok Barat." Tujuan dari program ini adalah untuk membantu menangani pengolahan produksi jagung yang tinggi di desa Babussalam agar memiliki nilai ekonomi yang tinggi. Metode yang digunakan adalah sosialisasi, pelatihan, dan pemasaran produk. Hasil yang didapatkan dari program ini adalah dapat mengubah pola pikir masyarakat dari penjualan bahan mentah menjadi pengolahan bahan mentah menjadi produk olahan. Hal ini tentunya memiliki dampak baik masyarakat sekitar dan perekonomiannya.
\end{abstract}

Kata Kunci: Jagung; Keripik; Pemberdayaan; Produk Olahan. 


\section{Pendahuluan}

Desa Babussalam terdiri dari sebelas dusun dan memiliki potensi unggulan di bidang pertanian, perkebunan, dan kerajinan. Desa ini memiliki Sumber Daya Alam (SDA) yang sangat melimpah. SDA tertinggi yang dimiliki desa Babussalam yaitu tanaman jagung. Desa Babussalam juga kaya akan Sumber Daya Manusia (SDM). Hal ini dapat dibuktikan dengan luas permukiman seluas $14,918 \mathrm{ha} / \mathrm{m}^{2}$ dengan jumlah penduduk sebanyak 9.278 jiwa (Profil Desa Babussalam, 2019).

Pertanian merupakan sektor utama dalam program dan strategi pemerintah untuk memecahkan angka kemiskinan. Sektor ini memperlihatkan hasil yang baik dan memberikan konstribusi penting dalam pertumbuhan ekonomi negara Indonesia, termasuk menciptakan lapangan pekerjaan dan mengurangi kemiskinan secara drastis. Hal tersebut memusatkan perhatian pada bahan-bahan pokok, salah satunya tumbuhan jagung. Akan tetapi, dengan adanya penurunan dalam hasil produktivitas panen dari hampir seluruh jenis bahan pokok, ditambah mayoritas petani yang bekerja di sawah kurang dari setengah hektar, aktivitas pertanian kehilangan potensi untuk menciptakan tambahan lapangan pekerjaan dan peningkatan penghasilan (Bank Dunia, 2010).

Berdasarkan data Profil Desa Babussalam (2019), ternyata hasil produksi pertanian yang terdapat di desa Babussalam hanya dipasarkan atau dijual secara mentahnya saja, sedangkan untuk pengolahannya masih tergolong sangat rendah atau dapat dikatakan belum ada. Hal tersebut dapat menyebabkan kehilangan potensi untuk menciptakan lapangan pekerjaan tambahan bagi masyarakat dan peningkatan penghasilan desa.

Jagung (Zea mays L.) merupakan komoditas pertanian yang memiliki sekitar 50.000 varietas, salah satunya yaitu jagung manis (Zea mays saccharata) sangat digemari terutama oleh penduduk perkotaan karena memiliki cita rasa yang lezat (Sudarsana, 2000). Tanaman ini digunakan sebagai bahan pangan yang penting karena merupakan sumber karbohidrat. Kandugan lain yang terkandung di dalam jagung yaitu pati (72$73 \%)$, kadar gula (1-3\%), dan protein $(8-11 \%)$ (Badan Penelitian dan Pengembangan Pertanian, 2012).

Zulviani (1992) menjelaskan bahwa pengolahan jagung di Provinsi Nusa Tenggara Barat (NTB) telah banyak dikembangkan di masyarakat luas. Pengembangan produk olahan dapat dilihat dari banyaknya produkproduk seperti kue, susu, es krim, bahkan keripik dengan berbahan dasar jagung manis. Pengolahan keripik merupakan salah satu produk olahan alternatif pangan yang dapat meningkatkan daya jual jagung.

Berdasarkan latar belakang di atas, maka dilakukan pengabdian Kuliah Kerja Nyata (KKN) dengan program "Pemberdayaan Masyarakat Melalui Pengolahan Keripik Jagung (Zea mays L.) dengan Varian Rasa di Desa Babussalam, Kecamatan Gerung, Kabupaten Nusa Tenggara Barat." Pengabdian KKN ini bertujuan untuk memberdayakan masyarakat melalui pengolahan keripik jagung yang memiliki keunggulan dalam wisata kuliner. Hal ini dapat menambah jumlah produk olahan khas desa Babussalam dengan memanfaatkan SDA yang melimpah. Pemanfaatan jagung ini juga diharapkan dapat membantu dalam segi ekonomi, yaitu dapat meningkatkan nilai jual jagung manis dan meingkatkan kesejahteraan masyarakat di desa Babussalam.

\section{Metode Pelaksanaan}

Sasaran dalam kegiatan pelatihan pembuatan kripik jagung ini adalah masyarakat Desa Babussalam, lebih tepatnya ibu-ibu yang tergabung di dalam Himpunan ibu-ibu Pemberdayaan Kesejahteraan Keluarga (PKK) di desa Babussalam. Metode yang digunakan dalam kegiatan ini adalah metode sosialisasi, pelatihan, dan 
pemasaran produk. Kegiatan ini dilaksanakan selama 15 hari, dimulai sejak tanggal 15-30 Januari 2020. Bertempat di Desa Babussalam, Kecamatan Gerung, Kabupaten Lombok Barat.

Alat yang digunakan dalam program ini adalah kompor, tabung gas, wajan, sutil, peniris minyak, baskom, nampan, penipis adonan, sendok makan, pisau, dan cetakan kue. Bahan-bahan yang digunakan yaitu jagung manis 2 bonggol, keju $35 \mathrm{~g}$, margarin $100 \mathrm{~g}$, tepung beras $10 \mathrm{~g}$, tepung terigu $300 \mathrm{~g}$, tepung maizena $10 \mathrm{~g}$, kaldu ayam, minyak goreng $1 \mathrm{~L}$, perasa makanan, telur 1 butir, bawang merah 5 siung, dan garam.

Sosialiasi Pembuatan Keripik Jagung, Perizinan Industri Rumah Tangga (PIRT), dan Pemasaran dilakukan menggunakan microphone, sound system, dan Liquid Crystal Display (LCD). Alat yang digunakan untuk pemasaran produk yaitu handphone.

Secara keseluruhan kegiatan ini yaitu 1)

Persiapan program, 2) Sosialisasi dan pelatihan pembuatan keripik jagung, 3) Sosialisasi PIRT dan pemasaran online, 4) Pemasaran produk, serta 5) Monitoring dan evaluasi. Metode pengumpulan data pada program ini dilakukan dengan cara survei jumlah produksi jagung di Desa Babussalam. Sedangkan analisis data yang digunakan adalah deskriptif kualitatif

\section{Hasil dan Pembahasan}

Program pembuatan keripik jagung ini dilakukan secara terstruktur dan melibatkan ibu-ibu PKK di desa Babussalam secara langasung.

\section{Persiapan Program.}

Kegiatan pemberdayaan masyarakat melalui pengolahan keripik jagung dimulai dengan persiapan program yang meliputi survei lokasi serta persiapan alat dan bahan pelatihan. Hasil survei serta persiapan alat da bahan menunjukkan bahwa kendala yang dihadapi 1) Kurangnya alat yang akan digunakan untuk pelatihan, 2) kurangnya minat masyarakat untuk mengikuti pelatihan pengolahan produk.

\section{Pelaksanaan Program Pemberdayaan Masyarakat Melalui Pengolahan Keripik Jagung}

Pelaksanaan program pemberdayaan masyarakat diselenggarakan pada tanggal 15 Januari 2020 yang bertujuan untuk menambah wawasan para ibu-ibu PKK tentang pemamfaatkan jagung manis. Kegiatan ini dimulai dengan menjelaskan tentang bagaimana mengolah hasil SDA yang dimiliki, apa saja keuntungan pengolahan tersebut, dan langkah-langkah prosedur pembuatan keripik jagung. Tujuan diadakannya program ini yaitu untuk menumbuhkan dan meningkatkan kesadaran masyarakat mengenai pengolahan SDA yang dimiliki Desa Babussalam dari bahan mentahnya menjadi produk jadi dengan nilai jual yang tinggi.

Pelaksanaan program ini berjalan dengan lancar. Hal ini dilihat dari proses pembekalan mengenai produk olahan dan pengaplikasikan ilmu yang sudah didapatkan untuk dipraktikkan langsung dalam bentuk pembuatan keripik jagung.

Adapun kendala yang dihadapi dari program ini adalah belum terpenuhinya target peserta yang diinginkan. Dalam program ini memiliki target peserta sejumlah 25 orang, namun pada pelaksanaannya hanya dihadiri oleh 18 peserta. Hal ini dikarenakan oleh kurangnya partisipasi masyarakat desa dengan program ini.

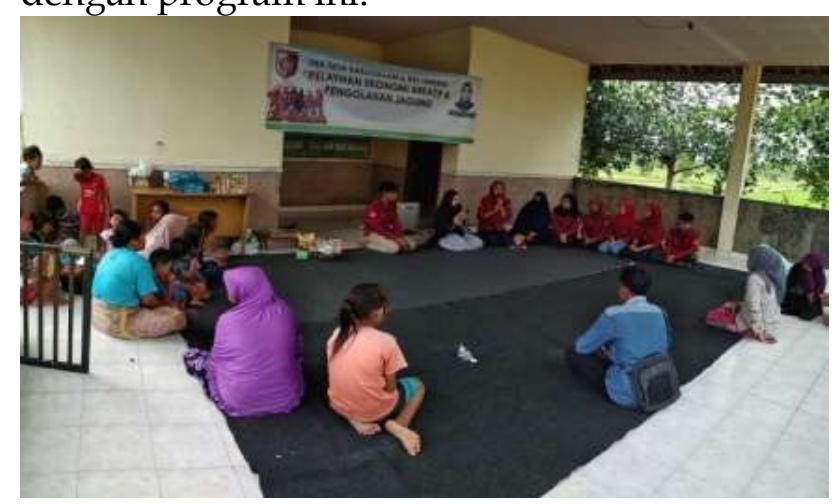

Gambar 1. Sosialisasi Keripik Jagung 


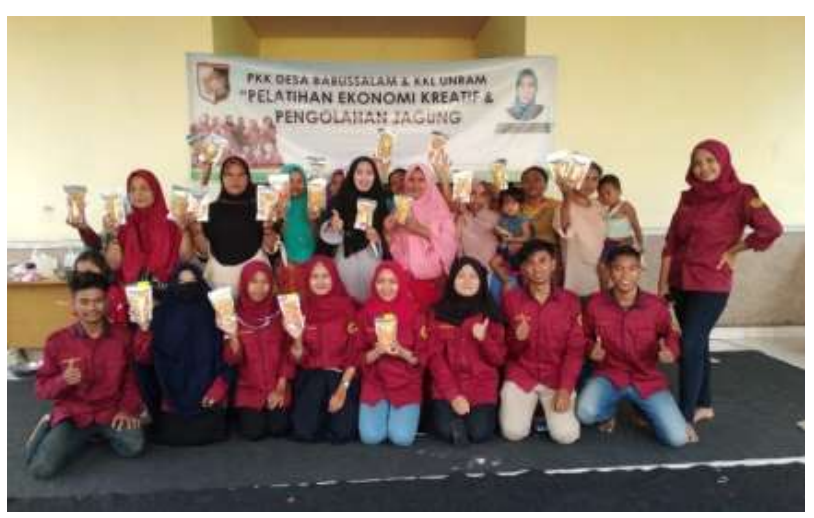

Gambar 2. Pelatihan Pengolahan Keripik Jagung

\section{Sosialisasi PIRT dan Pemasaran Online}

Tujuan dilakukannya sosialisasi PIRT diantaranya 1) untuk memberikan masyarakat pengetahuan bagaimana standar kelayakan suatu produk dapat dipasarkan. 2) untuk mengetahui tahapan pendaftaran perizinan suatu produk. Tujuan sosialisasi pemasaran online adalah agar masyarakat tahu bagaimana keuntungan apabila suatu produk dipasarkan melalui media online.

Pelaksaan kegiatan ini berjalan dengan lancar dan kondusif. Hal ini dilihat dari tercapainya target peserta dan antusias masyarakat yang tinggi.

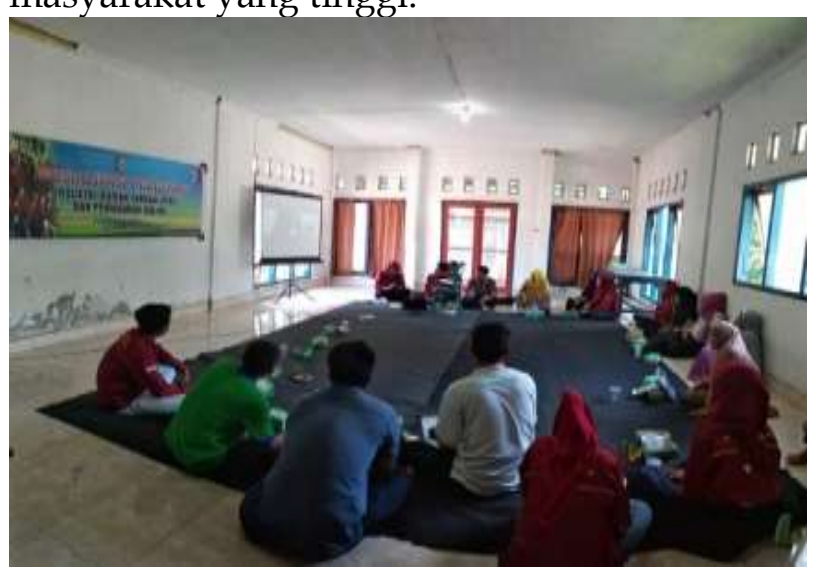

Gambar 3. Sosialisasi PIRT dan Pemasaran Online

\section{Pemasaran Produk}

Pada pemasaran produk keripik jagung ini dilakukan secara online (instagram dan whatsapp) dan offline (langsung). Target pemasaran dari penjualan produk ini adalah masyarakat Desa Babussalam dan masyarakat luas sekitar Lombok Barat.
Kendala dari pemasaran ini adalah kurangnya kepercayaan masyarakat terhadap produk ini. Hal ini dikarenakan belum adanya nomor PIRT yang dimiliki produk. Sehingga dapat mengakibatkan produk yang dipasarkan hanya terjual dengan sangat minim.
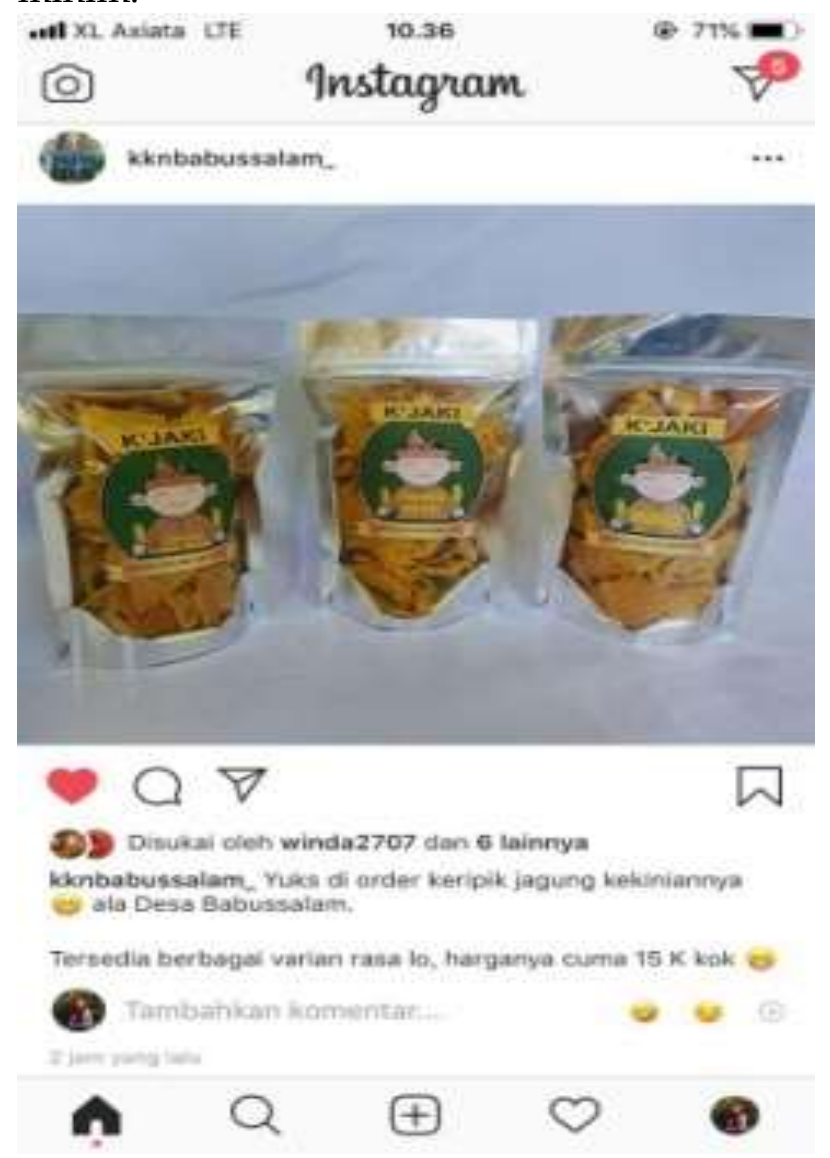

Gambar 4. Pemasaran Produk Melalui Sosial Media

\section{Monitoring dan Evaluasi}

Monitoring dan evaluasi kontinu dilakukan bersamaan dengan pedamping program. Hasil monitoring dan evaluasi program secara umum menunjukan bahwa masyarakat mampu memanfaatkan dan mengolah hasil pertanian, salah satunya jagung menjadi sesuatu yang memiliki harga ekonomis yang tinggi.

\section{Kesimpulan}

Simpulan dari program-program ini adalah: 1) Program pemberdayaan masyarakat melalui "Sosialisasi dan Pelatihan Pembuatan 
Keripik Jagung" dapat memberikan masyarakat Desa Babussalam pengetahuan dan sadar akan pentingnya pengolahan produk yaitu dengan cara mengolah bahan mentah menjadi produk jadi dan memiliki nilai ekonomi yang tinggi. Salah satu produk yang dapat dihasilkan yaitu keripik jagung. 2) Program pemberdayaan masyarakat melalui "Sosialiasi PIRT dan Pemasaran Online" dapat memberikan masyarakat desa Babussalam pengetahuan bagaimana standar kelayakan suatu produk dapat dipasarkan dan pentingnya pemasaran suatu produk menggunakan sistem online.

\section{Ucapan Terimakasih}

Pengabdian KKN ini dapat terlaksana atas kerjasama dari pihak LPPM, Desa Babussalam, dan dukungan dari dosen pembimbing lapangan Bapak Drs. Aris Doyan, M. Si., Ph. D., serta rekan-rekan seperjuangan $\mathrm{KKN}$ Universitas Mataram.

\section{Daftar Pustaka}

Badan Penelitian dan Pengembangan Pertanian. (2012). Aneka Olahan Jagung. Jakarta: IAARD Press.

Bank Dunia. (2016). Indonesia Expanding Horizons.

Siretesources.worldbank.org/INTINDONE SIA/Resources/Publication/280016/110613 0305439/617331-1110769011447/8102961110769073153/agriculture.pdf <akses 10 Januari 2020>

Profil Desa Babussalam Tahun 2019.

Sudarsana, R. (2000). Budi Daya Tanaman Jagung. Bandung: Pustaka Buana.

Zulviani. R. (1992). Pengaruh Berbagai Tingkat Suhu Penggorengan Terhadap Pola Pengembangan Kerupuk Sagu Goreng. Skripsi Jurusan Teknologi Pangan dan Gizi. Bogor: Institut Pertanian Bogor. 